\title{
The impact of attitudes towards influencers amongst millennial fashion buyers
}

\author{
Patricia SanMiguel, University of Navarra, ISEM Fashion Business School* \\ Simone Guercini, University of Florence, Department of Economics and Management \\ Teresa Sádaba, University of Navarra, ISEM Fashion Business School \\ ${ }^{*}$ Corresponding author: patricia.sanmiguel@isem.es
}

\begin{abstract}
The aim of this paper is to identify influencers and the way they affect the behavior of millennial buyers in the process of consuming fashion goods. The paper examines the literature on opinion leaders, ranging from the origins of the concept to its developments within the context of the Internet. The shift from influential to influencer and the different types of influencer are examined and certain hypotheses regarding the role of influencers (including all the influential players) regarding fashion-buying millennials are presented. The paper presents the results of qualitative and quantitative empirical research based on focus groups and in-depth interviews with 22 university students. Findings from this research and their implications regarding the different stages of the millennial buying process are discussed.
\end{abstract}

Keywords

buying behavior, influencer, opinion leaders, millennials, fashion.

\section{Introduction}

The first two decades of the twenty-first century have witnessed a number of key revolutions in the digital world. The widespread use of the Internet, the development of virtual communities and the creation of multiple devices (Castells, 2001) have transformed the way in which individuals interact and consume (Sádaba, 2015). Social media users can now connect with people from all parts of the world, establish real-time conversations and share opinions on products purchased around the five continents (Mir-Bernal, 2014).

In recent years, the social media has become a realm for participation and collaboration, one in which users have taken over the role of companies in the generation of content (Castells, 2001). Consumers live on the Internet and spend an increasing number of hours throughout the day surfing the net, leaving traces of everything they do, the things they like most or the sites they frequent. In the fashion industry, the Internet presents some significant benefits regarding development, growth and business internationalization and marketing strategies (Guercini and Runfola, 2015; Guercini et al., 2018).

Most fashion items become fads by a contagious effect. They are transmitted both by recommendation and by imitation, in a similar manner to an epidemic. Social media play a fundamental role in this transmission, whilst technology helps us to capture them. The fashion consumer is increasingly informed, prepared and connected to the online community (Sádaba, 2015). In this new scenario, the dissemination of fashion trends "does not exist as a force or an abstract idea, but is materialized through the actions of different agents and the mutual interaction amongst all of them" (Martínez Barreiro, 2006, p. 201).

Today, consumers have the ability to express their opinions, share their experiences and make recommendations, not only within their immediate circles, but within the entire online community thanks to the arrival of blogs, social media and smartphones (Sádaba \& SanMiguel, 2014; SanMiguel \& Sádaba, 2018). Some influentials (who previously only influenced their closest social circles) become 
influencers, featuring a status and form of recognition amongst a community of followers. So, with the generalization of the Internet, new kinds of definitions regarding influencers have appeared (Gillin, 2007; Johnson \& Young, 2012; Ranga \& Sharma, 2014).

Nowadays, when we talk about influencers, we mean celebrities, sportspersons, bloggers, Instagramers, Youtubers and consumers who can help companies broaden their reach and brand awareness for a specific target audience that follows their content in an active way. Their influence is based on the knowledge and passion they have regarding a specific theme. The frequent and continuous use of social media allows them to create a community and generate bonds of trust (Brown \& Hayes, 2008). In the case of celebrities or athletes, their influence is also due to the interest and admiration they generate amongst consumers.

As has been shown in previous studies (Sádaba \& SanMiguel, 2014), fashion influentials and influencers occupy a key position in the fashion industry through their blogs and social media. They assume the role of references, advisors, disseminators and models of behavior regarding the use and consumption of fashion products.

This study addresses the impact of influencers, including all the influential players, on fashion consumption and analyzes the role of these opinion leaders in the consumption process in relation to millennials. The paper include two main parts: 1. Review of literature on influencers, from the origins of the concept to its developments within the context of the Internet.; 2. Qualitative and quantitative empirical research through sample of focus groups and in-depth interviews based on university students from Madrid (Spain) born between 1999 and 1991 .

\section{Research objective and hypotheses}

Most current studies surrounding the influence phenomenon are largely limited to highlighting the role that influencers have as opinion leaders in relation to brand awareness and the dissemination of new products. These studies are usually carried out by communication and marketing agencies that evaluate their communities of followers and the engagement they generate, analyzing case studies of products with high sales volumes due to their relationship with influencers (Brown \& Hayes, 2008; Mediakix, 2016).

In academic terms, with the advent of the Internet, most studies that address the topic of opinion leaders have focused on the identification of influentials on the Internet (Agarwal et al., 2008; Akritidis et al., 2009, 2011; Song, et al., 2007). These studies have largely been carried out within the fields of the Information Sciences, Web Searching, Web Intelligence, etc.

Few studies have attempted to analyze the influence process through a more qualitative perspective. There is a gap in the literature regarding the role that influencers play during the buying process: what is the influencer's role in the generation of needs and product searches, regarding the evaluation of alternatives and in relation to purchase and post-purchase phenomena? And how can we typify influencers and the way they influence consumers?

\subsection{Objective}

The objective of the present study is to analyze those players that influence university students during the process of buying fashion products (clothing and accessories) and the ways in which this influence is exercised. To do this, we analyzed the following: 1) the fashion consumer profile of young university students; 2) how the purchase process of young university students works; 3 ) the different players that influence each stage of the process; and 4) the type of influence exercised by these players.

Before explaining the hypothesis of the study, it is necessary to clarify the following:

First, we shall understand the purchasing act as a process: the stages that a consumer follows once he has a need or creates a need and until he buys a product and uses it. 
Second, We shall focus on influential players: those people, media or brands that exercise influence by changing opinion or behavior in individuals. Third, we shall consider young university students: individuals residing in Madrid, between the ages of 18 and 25, who are studying a degree (postgraduate, master's or doctorate) at a university in Madrid, Spain.

\subsection{Hypotheses}

The general hypothesis of this research is that young university students are influenced throughout their buying process by different influential players. This hypothesis is made up of the following subhypotheses:

, H1: Despite the increase in influencers, close circles still play a key role in the evaluation and purchase decision stages.

, H2: The social groups that young people belong to continue to exercise a significant influence, despite growing individualism and the social trends that fashion proposes with the expression of a unique and personal identity.

, H3: Access to and purchase of products on the Internet is mostly through the mobile devices that young university students possess.

, H4: Instagram emerges as the new social media par excellence.

\section{The emergence of opinion leaders in the online age}

Internet has provided consumers with a new channel to disseminate their opinions, reaching a greater number of people than traditional word-of-mouth could achieve (Mir-Bernal, 2014). These conversations occur especially on social media such as WhatsApp, Facebook, Instagram and Twitter, where consumers provide or seek information and advice about products they wish to buy (Choi, Chiu, \& To, 2011).

Users share their opinions and experiences, having an impact on: 1) consumers, who can advise or discourage the acquisition of a product; and 2) brands, with which they can collaborate through the creation of brand values and the dissemination of messages (Harris \& Rae, 2009).

Multiple authors point out that eWOM (Electronic Word of Mouth) has a positive influence on the adoption of products, impacting consumers' awareness, interest and decision-making stages (De Bruyn \& Lilien, 2008, p. 153). Individuals need to support their shopping experience with information from peers, with other personal experiences (Yoon \& Han, 2012). However, not all individuals share information and influence consumers in the same way.

Web 2.0 has allowed the creation and distribution of content generated by users and it is within this context that the influencer phenomenon has emerged. According to the "Annual Social Networking Survey" produced by the Interactive Advertising Bureau (2017), 85\% of Internet users between 16 and 55 years of age state that they are still influenced through social media. They follow the profiles of those they consider to be "ahead" and they identify with the group, seeking inspiration or imitating their style.

Opinion leadership studies began in the 1940's with research by Katz \& Lazarsfeld and Merton and Weiman, and have continued up until the beginning of the second millennium. Since the 1950's, there has been talk of two types of leadership: formal leadership, which is assigned by the position of power held by certain people due to their social status or profession; and informal leadership, associated with people with "almost invisible and certainly unconscious leadership from person to person, intimate, and daily:" what are known as influentials (Katz \& Lazarsfeld, 2011, p. 140).

Internet enables consumers to take on a central role in spreading trends and opinions about brands (Zhang, Zhao, \& $\mathrm{Xu}, 2016)$ and, consequently, studies on the role of consumers as influencers have increased. In fact, some researchers have talked about the return of influence (Schaefer, 2012). Therefore, the Internet represents a boom in influence and a diversification of the types of influencers. 
The diversification of influencers is a consequence of the characteristics of the Internet, which 1) democratizes the message dissemination channels (creation of blogs and various platforms to share content), 2) trains individuals to create contacts with people from anywhere in the world, expanding networks and 3) increases the speed of message dissemination and increases the power of virulence (Jove, 2011).

Within this context, the term "influencer" has begun to be used to designate all those people who have the capacity to influence the online environment and whose power of influence is recognized by a community of followers and a large number of Internet users. The Internet transforms influentials (unofficial leaders) into influencers, opinion leaders with a public and official status within their communities of followers on social media.

In view of these changes, companies have had to adapt and find other ways to reach consumers, taking into account the fact that consumers increasingly demand close and transparent communication with companies (Cabosky, 2016). Within this context, the role of influencers is essential for spreading trends and bringing brands closer to consumers (Zhang et al., 2016). Consequently, new marketing strategies known as influencer marketing, which stands for "the art and science of involving people who are influential on the Internet to share brand messages with their audience, in the form of sponsored content" (Sammis et al., 2016, p. 12). That is to say, it is the means by which companies send messages to their audience through other consumers who share their story and generate interest.

It should be noted that popularity can be a by-product of influence or authority. But influence cannot be measured solely by the size of a community. Influence means having the ability to cause an effect or change a form of behavior (Solis \& Webber, 2012).

Research about the role of influencers regarding the decisions of consumers has continued to develop (Danny Brown \& Fiorella, 2013; Kiss \& Bichler, 2008; Song et al., 2007). It should be noted that many studies have been carried out by digital marketing companies that specialize in influencer marketing (Klout, 2013; Solis, 2016; WOMMA, 2017). Studies in the academic field have also been developed. Most have focused on what influencers are, marketing strategies with influencers and types of collaborations between brands and influencers (Galeotti \& Goyal, 2009; Uzunoğlu \& Misci Kip, 2014; Watts \& Dodds, 2007). However, there are few studies that analyze how influencing impacts from the point of view of consumers, as opposed to the perspective of marketing agencies or the influencers themselves.

In 1999, the RoperASW and BursonMarsteller companies conducted a study of online opinion leaders in the USA and called them "e-influentials" (Smith, 2007). A few years later Burson-Marsteller (2005) developed new research on opinion leaders in the field of technology: Next Generation of Influencers. The company Tapinfluence analyzed the effectiveness of sales through marketing with influencers and published a report entitled The Future of Influencer Marketing (2016). Mediakix, an influencer marketing agency, developed The COM'S Guide to Influencer Marketing (2016), in which it classifiedinfluentials through social platforms. The Altimeter company published The Influencer Marketing Manifesto: Why the Future of Influencer Marketing Starts with People and Relationships Not Popularity. This study notes: "the difference is, and this is important, that influential people have the same weight as their peers or 'people like me', which is among the highest forms of influence that are mentioned among consumers in one study after another" (Solis, 2016, p. 1).

The Word of Mouth Marketing Association, in its The WOMMA Guide to Influencer Marketing (2017), defines influence as the ability to cause or contribute to another person taking action or changing opinion/behavior. "An influencer is someone who has greater than average potential to influence others. The people who influencers affect are influencees, defined as a person or group of people who take 
action or change opinion/behavior as the result of exposure to information provided by an influencer. Influencer Marketing is the act of a marketer identifying and engaging influencers to share information with influence in pursuit of a business goal" (WOMMA, 2017, p. 4).

With the arrival of the Internet, influence began to be measured through "Big Data." Although there are multiple variables, an analysis of influentials usually focuses on three variables (Armano, 2011; Burke, 2016; Klout, 2013; Solis, 2017):

, Reach: the size of an influencer's following or audience size on any given social channel. Within that reach, the engaged reach is the size of audience within this following that will actually engage with the posts.

, Relevance: the alignment of the interests of an influencer - content that is published and what it offers - with the brand, the sector and its audience.

, Resonance: the quality of the influential-follower connection and its ability to influence the behavior and purchases of the community of followers.

Influencers are usually categorized into four groups according to the size of their community variables (Burke, 2016; Klout, 2013; Solis, 2017):

, Celebrities: actors, artists, sportspersons and other social media stars, they are also called mega influencers. They usually have more than one million followers.

, Mega influencers: bloggers, instangramers or experts in a subject who reach more than 1 million followers.

, Macro-influencers: executives, journalists, bloggers, Instagramers and YouTubers who reach around 1 million-10K followers.

, Micro-influencers: customers or employees who reach around $10 \mathrm{~K}-1 \mathrm{~K}$ followers.

In order to analyze the impact of the different players that influence consumer decisions, the influence of the media and surrounding circles was also analyzed. We understand "close circles" to mean friends, colleagues and neighbors who share opinions and advise. These close circles would be the influentials defined by Lazarasfeld anf Katz.

Nowadays, the dissemination of fashion trends occurs through a process of "virulence", which is an idea also suggested by Wiswede (1971). "It is a pattern of fashion dissemination 'by contagion' and a form of propagation such as AIDS or epidemics" (Martínez-Barreiro, 2006, p. 189). This process of dissemination by contagion was explained in a meticulous manner by Gladwell (2014), who emphasized the existence of individuals that accelerated the processes of dissemination. Literature has called these opinion leaders "influentials" (Katz \& Lazarsfeld, 1955; Keller \& Berry, 2003; Weimann, 1994).

The fashion process is understood as a form of collective behavior and a social mechanism of change, through which an object or trend is transmitted from its creation and introduction to society as a whole, accepting that product or tendency, until its obsolescence (Weimann, 1994).

In the course of these creations and disseminations, many players are involved (Crane, 1999): brands, designers, advertisers, agencies, magazines, etc. However, in the present study we will focus on the role of influencers, which are currently of great importance in the new consumer paradigm. Influencers are especially important amongst millennials and post-millennials.

Therefore, the present study is focused on the younger members of Generation Y, Spanish university students born between 1999 and 1991. Members of Generation Y, often called Millennials (Cantoni \& Tardini, 2010; Oblinger, Oblinger, \& Lippincott, 2005; Reeves \& Oh, 2008), frequently they are defined as people who were born between 1982 and 2002. We should point out that, as noted by Reeves and Oh (2008), there is no agreement regarding the range of years that defines millennials, so some authors talk about post-millennials when referring to those born at the beginning of 2000.

Millennials are the first generation to grow up surrounded by digital media and are accustomed to buying and socializing 
online (Howe \& Strauss, 2009; Reeves \& Oh, 2008; K. T. Smith, 2011). Millennials are the largest generation group since the baby boomers, constituting a key target for fashion companies (Portolese Dias, 2003; Smith, 2011; Smith, 2012). It should be noted that this generation has been denominated in multiple ways: Digital Natives; Gen.com; Generation Next; Generation Tech; Generation Why; Generation Y; Generation 2000; Instant-Message Generation (Cantoni \& Tardini, 2010; Rapetti \& Cantoni, 2013).

The massive advent of Information and Communication Technologies (ICTs) has significantly impacted people everyday life (Rapetti \& Cantoni, 2013). This impact produces differences between Millennials and older generations, therefore Generation Y has been analyzed by several researchers. The implications of the adoption of new technologies in everyday life and education have been analyzed mainly from three points of view: 1) enthusiasts, who think that new technologies make young people more capable and have different cognitive abilities; 2) stakeholders, who analyze the effects of ICT on young people, as they can be more violent and suffer addition or harassment; 3) critics, who criticize the lack of localized studies and analysis (Cantoni \& Tardini, 2010). This research can provide data on the testing of this generation in the case of Spain.

Several studies describe millennials as: happy, optimistic, confident, accepting of authority, cooperative, happy to play as a team, hopeful, goal- and achievement-oriented, civic-minded, inclusive, self-sufficient, technology savvy, connected, and open to change and diversity (Cantoni \& Tardini, 2010; Howe \& Strauss, 2009; Portolese Dias, 2003; Raines, 2002).

Smith (2011) points out that millennials are an essential ingredient in the development of electronic commerce, as they have grown up socializing and buying online (Smith, 2011, p. 489). Millennials consider computers and mobile phones to be essential tools. Through them they communicate, access digital newspapers, use social media and can buy anywhere in the world, which is why they are iden- tified as a driving force of online shopping (Fromm, Butler \& Dickey, 2015; Howe \& Strauss, 2009; Smith, 2011).

Millenials are a key target of influencer marketing (Pophal, 2016; Solis, 2016). Due to the great use of social media (Facebook, Instagram, YouTube, Twitter), especially amongst the youngest millennials - those born in the late 90's-, the influencer marketing phenomenon has impacted in a special way on these consumers. Some research highlights how social media have become their main source of information, which means they look for information created by consumers like them before making a purchase (Raines, 2002; Howe and Strauss, 2009; Smith, 2011; Smith, 2012).

\section{Methodology and results}

The present study features a qualitative and quantitative methodology based on focus groups and in-depth interviews.

, First, the data from the focus groups are presented where the role of influencers is most focused.

, Second, we analyze the in-depth interviews from a qualitative perspective.

, Third, we analyze the in-depth interviews from a quantitative perspective in order to offer a fashion consumer profile and some initial data in relation to influencers.

The present research differentiated between the buying process of men and women, which is why the focus groups were carried out separately, one with women and the other with men. The results of the analysis are shown comparatively between the genders. From a historical, sociological and marketing point of view, the use of, interest in and consumption of clothing and accessories shows great differences between both sexes, men and women. These differences were especially evident during the nineteenth and twentieth centuries, but have been present throughout history (Kruger \& Byker, 2009; Mitchell \& Walsh, 2004). Researchers such as Browne and Kaldenberg (1997), Auty and Elliott (1998) and O'Cass (2004) have shown that wom- 
en are more involved and more interested in fashion than men. The decision-making behavior of men and women in relation to fashion goods and style presents considerable differences (Mitchell \&Walsh, 2004).

Rocha et al. (2005) pointed out how gender was a key factor in fashion consumption studies; gender had a high impact on lifestyle attributes because women and men had different expectations about fashion products. Inequalities regarding consumption were also analyzed by Catalá (2007) and Crane (2012). Recent AIMC research (2015) points out that men prefer quality and brands, while women give greater importance to trends and sales.

\subsection{Focus groups}

Focus groups are a research technique preferably used in the field of social sciences. It is a "non-directive" technique whose purpose is the controlled production of a discourse by a group of subjects that are brought together for a limited period of time in order to discuss a certain topic proposed by the researcher (Gil Flores, 1993, p. 120). The technique of focus groups began in the 1940's, with Paul Lazarsfeld and Robert Merton (Onwuegbuzie et al., 2011), researchers who analyzed and discovered the key role of opinion leaders or influencers in the transmission of messages.

This research technique has been used frequently in market studies in order to define the social images of products and brands and analyze the opinions, assessments and reactions of consumers, especially before introducing a new product onto the market (Gil Flores, 1993; Morgan, 1996).

This qualitative research technique may be used to obtain information about products or even about a concept, service or institution. The researcher seeks to discover the focus group's perceptions, feelings, attitudes and ideas.

\subsection{Sample of focus groups}

As has been shown in multiple studies, the consumption of information and fashion products is very different between both sexes (Auty \& Elliott, 1998; Browne \& Kaldenberg, 1997; Crane, 2012; Kruger \& Byker, 2009; O'Cass, 2004). Therefore, in order to obtain quality information and facilitate discussion in the focus groups, individuals were separated by gender. Two focus groups were held: one with only young female university students and the other made up of young male university students.

Table 1: Data regarding the research focus groups

\begin{tabular}{|c|c|c|c|c|c|}
\hline \multicolumn{6}{|c|}{ Data regarding focus groups } \\
\hline \multicolumn{6}{|c|}{$\begin{array}{l}\text { Number of focus group conducted: } 2 \text { (one with men and another with women) } \\
\text { Number of participants in the focus group: in the first } 10 \text { women, in the second } 9 \text { men } \\
\text { Dates when women group were held: Thursday, May 4, 2017, at 7:30 p. m } \\
\text { Dates when man group were held: Thursday, April 27, 2017, at 7:30 p. m. } \\
\text { Duration: } 60 \text { minutes each group }\end{array}$} \\
\hline \multicolumn{3}{|c|}{ Data focus group university women } & \multicolumn{3}{|c|}{ Data focus group university men } \\
\hline $\begin{array}{l}\text { Women } \\
\text { Code } \\
\end{array}$ & & Education & $\begin{array}{l}\text { Man } \\
\text { Code } \\
\end{array}$ & Age & Education \\
\hline W 01 & 21 & Law & M 01 & 23 & Business \\
\hline W 02 & 22 & Pharmacy & M 02 & 19 & Psychology \\
\hline W 03 & 20 & Teaching & M 03 & 24 & Labour Relations and Human Resources \\
\hline W 04 & 19 & Tourism & M 04 & 23 & Fashion MBA \\
\hline W 05 & 19 & Advertising and Public Relations & M 05 & 25 & Corporate Communication \\
\hline W 06 & 22 & Management & M 06 & 19 & Managment \\
\hline W 07 & 20 & Psychology & M 07 & 19 & Advertising and Public Relations \\
\hline W 08 & 21 & Protocol and Organization of Events & M 08 & 20 & Marketing \\
\hline W 09 & 24 & Political Science & M 09 & 23 & Agricultural Engineering \\
\hline W 10 & 19 & Sports Science & & & \\
\hline
\end{tabular}


The selection of the sample was carried out in a standard manner, appealing to the convenience of obtaining a sample that represents multiple profiles: fashion-lovers and non-fashion-lovers; age range; different universities and degrees. Within the homogeneity, a certain heterogeneity was sought in terms of sociodemographic characteristics, areas of study and interest in fashion, in order to increase the breadth of experiences, perceptions and opinions that could be contributed by the participants.

The focus groups were held in a meeting room at the University of Navarre in Madrid, an open space that facilitated conversation amongst all the members of the group and permitted the participants to see one another. The discussion group was recorded with a tape recorder and filmed for only 15 minutes, with the aim of not inhibiting the participants, since they might feel thatvideo was an intrusive medium, as indicated by Morgan (1996). The characteristics of the focus groups that were held are summarized in Table 1.

\subsection{Analysis and results of focus groups}

The analysis is situated at a descriptive level and is presented through a narrative report, as advised by Gil Flores (1993). Following the recommendations of Onwuegbuzie et al. (2011), the analysis was expounded in three stages: 1) the data was fragmented into small units, assigning them descriptors; 2) the fragments were grouped according to the established descriptors; and 3) a report was developed expressing the content according to the established themes and descriptors. Furthermore, based on the guidelines and recommendations of Morgan (1996) and Onwuegbuzie et al. (2011), some microanalysis of the gathered data was carried out. For this reason, on occasion our presentation of the data includes certain statements such as "the whole group agreed...," "all but one use...," "the majority buys..." These statements were made during the group discussion, with the moderator also carrying out a microanalysis of some variables that were being discussed.
The descriptors were linked to the categories discussed during the session: what fashion is and its importance at a dayto-day level; ways of consuming fashion; brand preference, platforms, styles; influential players in everyday fashion consumption; and the use of social media and their relationship with influencers. Subsequently, comparisons of the answers were made within each discussion group and between the two focus groups of different genders, in order to identify the consumption processes,profiles of consumers, and the influence path.

The most significant data extracted during the focus group dynamics emphasized the relationship and differences between both genders and the different characteristics of the participants (Table 2).

Today both men and women give importance to fashion. It represents their own image and the way of presenting themselves to the world: "I like fashion, it's a way of expressing myself" (W04). They are concerned about the opinion that others may have of their dress and personal style. Women give more importance to the differentiation of their personality through fashion: "I have my own style, I do not like to dress like the rest of my friends" (W10). Most men dress like their group of friends does and do not have as much need for differentiation.

The influence of negative comments is greater amongst women than amongst men."Most of the time we dress in a similar way, although if I buy some shoes and my friend doesn't like them, I don't care" (M07). They buy fashion alone in a physical manner, but accompanied in an online manner. "I tend to be alone when I buy something, but most of the time while I'm buying I send a picture to my sister or my best friend; they know me well and they usually advise me" (W08).

Regarding social media: men, in general, are more passive users and spend fewer hours on them, but both see content daily through this application. Men follow some female influencers because they like to see images of pretty girls: "I don't follow many influencers, although from time to time I see profiles of the best-known influ- 
Table 2: Main results from the focus groups

\begin{tabular}{|c|c|c|c|}
\hline Theme & Main result & Male behavior & Female behavior \\
\hline $\begin{array}{l}\text { Interest and importance } \\
\text { of fashion }\end{array}$ & $\begin{array}{l}\text { For both genders, fashion is } \\
\text { important; it is a way of } \\
\text { expressing your personality }\end{array}$ & $\begin{array}{l}\text { Some men dress out of necessity, } \\
\text { but do not give importance to } \\
\text { fashion }\end{array}$ & $\begin{array}{l}\text { Women give more importance to } \\
\text { fashion as a symbol of belonging } \\
\text { to the group and differentiation } \\
\text { of their personality }\end{array}$ \\
\hline \multirow[t]{2}{*}{ Influenced by } & Close circles & & \\
\hline & & $\begin{array}{l}\text { Family and by the group more } \\
\text { globally. }\end{array}$ & $\begin{array}{l}\text { The pressure of the group is } \\
\text { greater for women. Friends } \\
\text { can determine the use or not of } \\
\text { a certain look }\end{array}$ \\
\hline $\begin{array}{l}\text { Why do you buy clothes and } \\
\text { accessories? }\end{array}$ & On impulse, I create a need & $\begin{array}{l}\text { Only when I really need } \\
\text { something }\end{array}$ & $\begin{array}{l}\text { On impulse, because I like it } \\
\text { or because it's fashionable }\end{array}$ \\
\hline $\begin{array}{l}\text { Visit online stores or fashion } \\
\text { related websites? }\end{array}$ & Weekly & $\begin{array}{l}\text { Only when I need to buy } \\
\text { (except for those men who really } \\
\text { like fashion, who would visit } \\
\text { websites more frequently) }\end{array}$ & Daily or weekly \\
\hline Buy online & Once a semester & $\begin{array}{l}\text { Specific products } \\
\text { (such as sneakers) }\end{array}$ & $\begin{array}{l}\text { Once a month, in sales and } \\
\text { promotions. Buy more than one } \\
\text { product in each order. Websites: } \\
\text { ASOS, Wallapop, Amazon ... }\end{array}$ \\
\hline Go shopping & $\begin{array}{l}\text { Shop alone. What influences } \\
\text { them the most is the price }\end{array}$ & $\begin{array}{l}\text { When they want to buy a } \\
\text { necessary product or replace } \\
\text { a garment. Buy for special } \\
\text { occasions - with someone close } \\
\text { or somebody familiar }\end{array}$ & $\begin{array}{l}\text { Usually alone, sometimes with } \\
\text { a close friend. }\end{array}$ \\
\hline \multirow[t]{2}{*}{ Social media } & $\begin{array}{l}\text { Instagram main social media } \\
\text { Daily use }\end{array}$ & $\begin{array}{l}\text { Passive users and spend fewer } \\
\text { hours than women }\end{array}$ & Active users \\
\hline & & Follow some influencers & $\begin{array}{l}\text { Follow many influencers } \\
\text { as a source of inspiration }\end{array}$ \\
\hline $\begin{array}{l}\text { Sharing information about } \\
\text { purchases }\end{array}$ & $\begin{array}{l}\text { To ask for an opinion, through } \\
\text { WhatsApp }\end{array}$ & With mothers or couple & With close friends or sisters \\
\hline Regarding influencers & $\begin{array}{l}\text { Follow influencers on Instagram } \\
\text { and YouTube. } \\
\text { Influencers are sources of } \\
\text { information. } \\
\text { Massification of influencer } \\
\text { Little consumer loyalty towards } \\
\text { the influential }\end{array}$ & $\begin{array}{l}\text { Follow few influencers, but } \\
\text { especially related to sports or } \\
\text { some passion such as fine food, } \\
\text { cars or photography. } \\
\text { They do not have much impact } \\
\text { when it comes to buying clothes }\end{array}$ & $\begin{array}{l}\text { They follow many influencers } \\
\text { in all areas. Influencers influence } \\
\text { them by inspiring them, gener- } \\
\text { ating new needs and serving as } \\
\text { role models }\end{array}$ \\
\hline
\end{tabular}

Source: Compiled by authors

encers... they are very pretty girls" (M08). Only those men with the greatest interest in fashion and lifestyle claimed to follow profiles of male influencers frequently; but, in general, influencers don't make any impact when they buy. Women follow influencers for inspiration, to be informed of the latest trends or for gossip. Men and women both believe that many influencers work with brands as if they were models and that they wear clothes from some brands because they are paid to do so.
Men do not care much if the influencers have contracts with brands and do not show much interest in the personal life of the influencers. By contrast, most of the women indicated an interest in the personal life of the influencers. Women follow influencers of all kinds, related to fashion, lifestyle, sports, gastronomy, travel, actresses... They believe that many influencers lose their personal style because of their collaborations with brands and that they become advertisements: "some influ- 
encers have lost their personal style, brands give them a lot of money, but they lose their personality and they all end up being the same" (W03). They follow important influencers in order to stay up to date. They like photographs, but they know that they will not be able to buy many of the products that influencers wear. They like to follow small-scale influencers that look more like them and have a style that they can imitate more easily. For them, influencers are a source of inspiration and information about new brands or trends.

Men and women emphasize that, today, there is a certain massification of influencers due to social media: "Many people want to be influential to get brands to give them products or earn a bit of 'money', not everyone gets to be influential, I guess it depends on luck, a nice body and skill using social media" (W06). Among the skills to be influential, the following aspects were highlighted: the importance of being photogenic, the quality of photographs, having an attractive and fun personality for videos, and being well connected with other famous influencers. Participants in the focus groups emphasized two ideas: 1) they do not always follow the same influencers or pay them equal attention; they often get tired of seeing the photos or the life of the same person for a long time; 2) the consumer seeks creativity and authenticity in the contents published by the influencers, which is why each person follows certain influencers that they like and are often not known, although they also continue to follow famous influencers because everyone talks about them.

It should be noted that impulse purchases and the acquisition of garments that are not necessary are increasing. The majority of these impulse purchases are caused by continuous visits to the websites of brands and by the impact of influencers on Instagram, the result of generating a constant desire for products and new ideas. In addition, the appearance of new pages or apps such as 21Buttons (www.21buttons.com) facilitates finding information more easily and results in the consumption of the same products as those posted by influencers on social media.

\subsection{Qualitative analysis of in-depth} interviews: focus on influencers

After the focus groups were held, some 22 in-depth interviews were conducted in order to analyze and deepen our understanding of the opinion held by young university students regarding influencers and the different players that influence them during the process of purchasing clothes and accessories.

In-depth interviews are a qualitative research technique "in which one person (the interviewer) requests information from another or from a group (interviewees, respondents) to obtain data regarding a particular aspect. It presupposes, therefore, the existence of at least two persons and the possibility of verbal interaction" (Gil Flores, 1993, p. 167).

The steps regarding this qualitative access to our knowledge of social reality can be determined by the following points (Olabuénaga \& Ispizua, 1989, p. 30): 1) entering the process of social construction, reconstructing the concepts and actions of the studied situation; 2) describing and understanding the detailed means through which subjects embark on meaningful actions and create a world of their own and of others; 3 ) knowing how to create the basic structure of experience, its meaning, its maintenance and participation through language and other symbolic constructions; 4) making use of in-depth descriptions, reducing analysis to areas limited to experience, through immersion in the contexts in which it occurs.

\subsection{Characteristics and sample of in-depth interviews}

The in-depth interviews proposed for the present study were semi-structured interviews Each interview lasted between sixty and ninety minutes and they were divided into two parts. First, a broad conversation took place regarding the participants' interest in fashion, the fashion concept, the ways young people buy things, their personality and their environment (how their friends, hobbies, characteristics of their social environment were defined, groups, friends, etc.). In addition, they talked about the question of influencers (what they 
Table 3: Data regarding the in-depth interviews

\begin{tabular}{|c|c|c|c|}
\hline \multicolumn{4}{|c|}{ Data in-depth interviews } \\
\hline \multicolumn{4}{|c|}{$\begin{array}{l}\text { Number of in-depth interviews conducted: } 22 \text { in-depth interviews ( } 11 \text { with women and } 11 \text { with men) } \\
\text { Dates: The interviews were conducted in the month of May } 2017 \\
\text { Duration: between } 60 \text { and } 90 \text { minutes }\end{array}$} \\
\hline Case & Gender & Age & Education \\
\hline$\overline{W 01}$ & Woman & 22 & Journalism \\
\hline W02 & Woman & 23 & Architecture \\
\hline W03 & Woman & 19 & Civil engineering \\
\hline W04 & Woman & 24 & Political science \\
\hline W05 & Woman & 25 & Teaching \\
\hline W06 & Woman & 22 & Law \\
\hline W07 & Woman & 22 & Journalism \\
\hline W08 & Woman & 21 & Protocol and organization of events \\
\hline W09 & Woman & 25 & Pedagogy \\
\hline W10 & Woman & 20 & Children's education \\
\hline W11 & Woman & 22 & Nursing/Telecommunications \\
\hline M12 & Man & 21 & engineering \\
\hline M13 & Man & 25 & Marketing \\
\hline M14 & Man & 24 & Architecture \\
\hline M15 & Man & 21 & Literature and philosophy \\
\hline M16 & Man & 21 & Law \\
\hline M17 & Man & 19 & Advertising and PR \\
\hline M18 & Man & 23 & Industrial engineering \\
\hline M19 & Man & 21 & Economics \\
\hline M20 & Man & 24 & Business management \\
\hline M21 & Man & 20 & Medicine \\
\hline M22 & Man & 23 & Industrial engineering \\
\hline
\end{tabular}

Source: Compiled by authors

thought of them, what they served for and who they followed). Second, more specific questions were asked, obeying an order (pragmatic level), content (semantic level) and general guidelines (normative level) required in a standard questionnaire, with the objective of obtaining systematized and equal information in the form and order of all the interviewed cases (Berganza \& Ruiz, 2005). The interviewer was a similar age to that of the interviewees, an aspect that may have helped to overcome the distance between the researcher and the interviewee and may have favored communication (Guercini, 2014).

For this purpose, some 22 persons, 11 female university students and 11 male university students residing in Madrid, were selected. The selection of these 22 cases was carried out for convenience. The sampling of typical cases provided information from certain cases judged representative of the whole (Estrada \& Deslauriers, 2011), with the aim of obtaining profiles that broadly represent university students. In this respect, the respondents featured different ages, areas of study and different degrees of interest in fashion (Table 3 ).

\subsection{Findings from the qualitative analysis of the in-depth interviews}

The following is a summary of the results and findings from the interviews and a brief comparison of different aspects regarding men and women.

With regard to the activities that most young university students pursue in their free time, we might highlight the following: listening to music, surfing the Internet, and being with friends and family. We can confirm that the Internet plays an essential role in their day-to-day lives. All the university students interviewed claimed to constantly use their mobile devices, and heavily use WhatsApp and the social media, Instagram. In most cases the participants claimed that the latter is their favorite social media and they also stated 
Table 4: $\quad$ Main results from the in-depth interviews

\begin{tabular}{|c|c|c|c|}
\hline Theme & Main result & Male behavior & Female behavior \\
\hline Instagram & $\begin{array}{l}\text { Favorite social media } \\
\text { Average of } 5 \text { hours a day }\end{array}$ & $\begin{array}{l}\text { They like to see photos; } \\
\text { it entertains them }\end{array}$ & Generates wishes and needs \\
\hline Opinion about influencers & Opinion about influencers & $\begin{array}{l}\text { They don't have an opinion } \\
\text { about influencers; they do } \\
\text { not care much for influencers } \\
\text { because they do not help them } \\
\text { at all }\end{array}$ & $\begin{array}{l}\text { Influencers are a showcase } \\
\text { for brands, although they are } \\
\text { becoming more superficial } \\
\text { They like how they dress and } \\
\text { they find them inspiring } \\
\text { Through influencers they } \\
\text { discover new trends and ideas } \\
\text { about how to dress }\end{array}$ \\
\hline $\begin{array}{l}\text { Impact of influencers regarding } \\
\text { purchase }\end{array}$ & $\begin{array}{l}\text { Generates needs and a desire } \\
\text { to be like them }\end{array}$ & $\begin{array}{l}\text { Influencers have no influence on } \\
\text { them when they go shopping }\end{array}$ & $\begin{array}{l}\text { They would like to look like } \\
\text { their influencers, because they } \\
\text { always wear the latest fashion }\end{array}$ \\
\hline Favorite fashion influencer & & $\begin{array}{l}\text { Jon Kortajarena, Mariano } \\
\text { Di Vaio, Sergio Carvajal and } \\
\text { Marc Forné }\end{array}$ & $\begin{array}{l}\text { Maria Pombo, Lovely Pepa, } \\
\text { Dulceida, Mypeptoes, } \\
\text { Inés Arroyo, Marta Lozano and } \\
\text { Mery Turiel }\end{array}$ \\
\hline Influence of their close circles & $\begin{array}{l}\text { Take their opinion into account } \\
\text { and come to them for advice } \\
\text { They trust their opinion and } \\
\text { value the fact that they tell them } \\
\text { the truth }\end{array}$ & Mother, Couple & Mother, Sisters, Best friends \\
\hline
\end{tabular}

Source: Compiled by authors

that they spend an average of 5 hours a day using the app. Most young women interviewed declared that "Instagram often generates wishes and needs."

During the in-depth interviews the types of influencers were explained and examples of Spanish influencers were put in place so that they could identify what type of influencers they followed and which influenced them the most.

Women believe that influencers are becoming more superficial and the content seems to be very similar amongst all of them. Despite this, through influencers women discover how to dress successfully and this influences them when they buy. Men do not usually have any opinion about influencers because they do not care for them much. Men state that influencers have no power over them when they go shopping.

When asked about the influence of their close circles, two ideas stood out. On the one hand, mothers, sisters and closest friends advise them the best, because they already know them. They state this because "as they love us, they would never let us go poorly dressed on the street" (wom- an interviewed) and so they take their opinion into account and come to them for advice. On the other hand, it is a desire to belong to the group that makes them look alike and influence one other. In addition, two of the cases analyzed declared that they almost never ask for advice and, if they do, it is not to question if something is attractive or ugly; they are more interested in whether a garment suits them or not.

All but one of the men interviewed were influenced by the opinions of their close circles, because they consider that they are people who care about them and always want the best for them. Within this circle, the role of mothers and girlfriends as influential people is highlighted.

\subsection{Quantitative analysis of the interviews: focus on purchasing processes}

As a result of the quantitative analysis of the 22 in-depth interviews, through a set of closed questions we were able to discuss the following: A) behavior on the Internet; B) profile as fashion consumers; C) impact of influentials on the purchasing process. 


\section{A Behavior on the internet}

Interviewed university students use computers or laptops mainly at home $(68 \%$ only use it at home). Some $64 \%$ stated that they use a laptop or PC around 1 to 3 hours a day. Some $68 \%$ of the cases analyzed do not use tablets, and when these are used, it is mainly at home. Regarding the use of Smartphones, $100 \%$ of cases stated that they always have them with them and $77 \%$ use it actively for over 6 hours a day.

Social media. Only four individuals stated that they did not have Instagram and $73 \%$ were dynamic users of this social media, actively interacting and sharing content. Some $50 \%$ stated that they use Instagram between 3 and 6 hours a day. Regarding Facebook, only one individual claimed not to have an account, whilst $54 \%$ were dynamic users of this social media. Some $18 \%$ declared that they use Facebook between 3 and 6 hours a day, while $45 \%$ used it for less than an hour a day.

In relation to Snapchat, $86 \%$ of cases claimed not to use this social media and only two of the cases did so in an active manner. The use of Twitter was also limited, with $77 \%$ of cases claiming not to use Twitter and only two doing so actively. Finally, $64 \%$ watched videos on YouTube, although only four of the respondents used this platform in an active manner, interacting with the content. When asked about their favorite social media, $68 \%$ claimed that it was Instagram, whilst $27 \%$ claimed it was Facebook.

\section{B Profile of fashion consumers}

To operationalize the consumer profiles in relation to the Roger model, we constructed sentences to define each of the five profiles and then asked the participants to define themselves by selecting one of them (self-definition) and explain why they identified with that profile. The sentences to define the Roger's profiles were the followings: "Innovative" I wear what I like and I usually wear things that later become fashionable; "Adoptant early" I am one of the first in my group to wear something new that nobody has yet, but who has seen it in magazines or influencers; "Early majority" I am one of those who bought things in stores before sales and still do not carry everyone; "Late majority" I am one of the latest trends when I already have many people from my environment and I buy in sales; "Lagger" I wear things that have been in fashion and in stores for a long time, and I find it hard to carry new things and risk.

With respect to the adoption of trends in relation to the Rogers curve (2010), only $4 \%$ of the cases were defined as innovative, $13 \%$ of them were early adopters, $36 \%$ formed part of the early majority, $18 \%$ were part of the late majority and $27 \%$ were laggards. In relation to the interest that fashion produces, seven of the respondents (32\%) declared that it generated little interest and the remaining $68 \%$ stated that it generated interest or considerable interest. Half of the sample $(50 \%)$ claimed not to be fashion-lovers, whilst $40 \%$ of the respondents stated that they gave little importance to fashion.

Some $27 \%$ buy clothes and/or accessories every 15 days and highlight the periods of discounts and promotions as key purchasing moments. With regard to expenditure on clothes per month, ten of the cases spend between 0-50 euros, seven between 50-70 euros, three between 100 150 euros and two more than 150 euros. The majority of students (64\%) buy clothes and accessories with their parents' money. Sometimes parents give them money and other parents go shopping with their children and pay for the products. $36 \%$ of the students claimed to purchase most of the clothing and accessories with the money earned from their work. They usually work in part-time jobs or sporadic jobs (eg, some women claimed to be nannies or waitresses). Although the most expensive products or clothes for special occasions, such as weddings or parties, are paid by their parents. The most frequent moment for buying is during the weekend (82\%) and the purchases take place mainly in high streets and with the brands of large retailers.

Only three of the cases stated that they did not buy online; the rest bought online, especially during sales or promotions, at night or from their laptop. Only a minori- 
Table 5: The impact of fashion influence players on the purchasing process

\begin{tabular}{|c|c|c|}
\hline Stage & Action & Influencer \\
\hline \multirow[t]{4}{*}{$\begin{array}{l}1^{\text {st }}-\text { Need } \\
\quad \text { (or generation of the desire to buy) }\end{array}$} & Help me build my own personal style by inspiring me & $\begin{array}{l}\text { Close circles } \\
\text { Macro influencer } \\
\text { Mega influencer }\end{array}$ \\
\hline & Copying their looks & $\begin{array}{l}\text { Close circles } \\
\text { Mega influencer } \\
\text { Macro influencer }\end{array}$ \\
\hline & Help me discover new brands or products & $\begin{array}{l}\text { Close circles } \\
\text { Macro influencer } \\
\text { Mega influencer }\end{array}$ \\
\hline & Generate new needs & $\begin{array}{l}\text { Close circles } \\
\text { Micro influencer } \\
\text { Macro influencer }\end{array}$ \\
\hline \multirow[t]{2}{*}{$2^{\text {nd }}-$ Product search } & When I look for a product I look at the clothes and brands people wear & $\begin{array}{l}\text { Close circles } \\
\text { Macro influencer } \\
\text { Micro influencer }\end{array}$ \\
\hline & Who do you ask fashion advice from? & $\begin{array}{l}\text { Close circles } \\
\text { Macro influencer } \\
\text { Mega influencer }\end{array}$ \\
\hline \multirow[t]{2}{*}{$3^{\text {rd }}-$ Evaluation of alternatives } & $\begin{array}{l}\text { When deciding on choosing to buy one thing or another what influenc- } \\
\text { es you the most? }\end{array}$ & $\begin{array}{l}\text { Close circles } \\
\text { Macro influencer } \\
\text { Mega influencer }\end{array}$ \\
\hline & Changing your opinion based on your advice or photos you see & $\begin{array}{l}\text { Close circles } \\
\text { Macro influencer } \\
\text { Micro influencer }\end{array}$ \\
\hline $4^{\text {th }}-$ Purchase & How much their opinion influences when it comes to buying & $\begin{array}{l}\text { Close circles } \\
\text { Macro influencer } \\
\text { Mega influencer }\end{array}$ \\
\hline \multirow[t]{3}{*}{$5^{\text {th }}-$ Post purchase } & Who do you tend to compare and ask for opinion your purchases with? & $\begin{array}{l}\text { Close circles } \\
\text { Macro influencer } \\
\text { Micro influencer }\end{array}$ \\
\hline & $\begin{array}{l}\text { You would change some of your purchases because of the opinion they } \\
\text { give you or the images you see }\end{array}$ & $\begin{array}{l}\text { Close circles } \\
\text { Macro influencer } \\
\text { Micro influencer }\end{array}$ \\
\hline & Who do you tell or show what you usually buy? & $\begin{array}{l}\text { Close circles } \\
\text { Micro influencer } \\
\text { Macro influencer }\end{array}$ \\
\hline
\end{tabular}

ty of the respondents (31\%) bought online through their mobile phones.

We can highlight the fact that $82 \%$ buy most frequently in physical stores. Some $59 \%$ stated they bought for reasons of necessity, and mainly in stores and shopping centers. $36 \%$ because they were looking for products, or they were visiting a store or they were looking at websites and decided to buy a product in a more impulsive manner; only $4 \%$ declared that they purchased fashion in order to socialize. It is noteworthy that $55 \%$ declared that they gave importance or considerable importance to the opinion of other individuals. Some $50 \%$ of the cases could be defined as customers who researched online and shopped, this online research being carried out mainly through their Smartphone $(60 \%)$. Most of these cases $(86 \%)$ granted considerable importance to the price and they defined themselves as loyal to the brands they like. On the contrary, only $22 \%$ gave importance to the method of production of the garments and whether these methods were sustainable.

\section{Impact of Influencers on the Purchasing Process}

The processes of identification-creation of a need, desire to buy whimsically, the search for products and payment, are stages that are mainly performed alone. On the contrary, the stages of evaluation, 
purchase and post-purchase, are carried out in the company of other individuals, emphasizing evaluation with friends, and the purchase and search for feedback with the couple.

During the stages of the purchasing process, different aspects were analyzed and those players who were most influencial at each moment (media, celebrities, mega influencers, macro influencers, micro influencers and close circles) were identified, as indicated in Table 5 . We operationalized the influence using a 1-5 scale, where 1 means no influence and 5 completely influenced.

The results obtained were present in all stages and circumstances analyzed: respondents were most influenced by their close circles, followed by medium influencers and small influencers. All data and tables are presented in Appendix 1.

\section{Conclusions, limitations and future research}

Interviewed, both men and women, are consumers strongly influenced by social media and influencers. Through these channels they generate wants and create needs throughout the time they spend viewing content online. They are hyperinformed, constantly discovering new products and seeking information about them through social media, leading them eventually, in many cases, to the store. In relation to the hypothesis of the investigation we can point out:

Hypothesis 1 and 2 has been validated. The influence of the close circles (family and friends), the ones that Lazarsfeld and Katz (1955) analyzed explaining the role of influentials, is stronger in the entire purchasing process of the analyzed young millennials than the influence of digital influencers.

By contrast, small influencers, especially people from close circles, are associated with a passion for fashion as a hobby, not as a profit-making exercise. Their recommendations are made with genuine sincerity and they make them in your best interests. They know and advise you and do not have the end goal of wanting to sell you a product.

Although all university students find confidence in the recommendations made by their group and imitate their style, it is important to note how women also receive confidence from what they see amongst influencers, who serve as a point of reference and an indicator that something is fashionable. On the contrary for men, influencers do not provide a source of confidence and self-esteem. Men prefer the advice of their mothers or partners.

Regarding influencers players amongst millennials, both influencers and people in close circles (family and friends) have a great deal of weight in decision-making before young people consume clothing and accessories. When analyzing the stages of the purchasing process or the customer journey, we can observe that influencers have a greater role in the stage of inspiration and during the search for products. On the contrary, close circles are the ones that influence more clearly in the stages of evaluation, purchase and post-purchase.

Hypothesis 3 and 4 has been validated. The most commonly used devices are smartphones. Smartphones are used throughout the day, especially to be connected through WhatsApp and social media. Among the latter, Instagram is the most popular social media used. University women use it more actively by posting pictures and stories, while men use it in a more passive way. Both genders spend an average of 5 hours a day using this means of social media.

Following our analysis of the interviews and focus groups, we can conclude that the great influencers are linked with monetary arrangements with brands and are seen as a new advertising media and as models of aspirational behavior.

In terms of managerial implications, communication companies and fashion brands must make the right choice of influencer when creating a campaign to boost their marketing strategy, since each type of influencer plays a greater role in each of the different stages of the purchasing process. 
The prodigious influence of close circles and micro- and macro-influencers seems to be key. This idea confirms the studies regarding opinion leaders conducted in the 1950's and 1960's: the Internet, the processes of virulence that the social media entails, the importance of one to one, and the importance of WOM or e-WOM in close circles.

The limitations of this study are focused on the sample. The study has focused on millennials so their conclusions can't be extrapolated to other generations. In the same way, the study has focused on Madrid (Spain), the conclusions can be applied to the whole country but it would be necessary to analyze the influential players in other nations. Finally, this study has focused on the purchase of fashion products, in the future other research should analyze the power of influencers and close circles in other sectors.

The same limits can be overcome through future research. This study faces issues related both to defining the influential players and the generation to which the influenced buyers belong. In this paper we focused on influencers and millennials, but a more inclusive perspective is suggested, including other influential players and post-millennials. This is in part discussed in the paper but can be part of future research paths.

\section{References}

Agarwal, N., Liu, H., Tang, L., \& Yu, P. S. (2008). Identifying the influential bloggers in a community. Proceedings of the international conference on Web search and web data mining - WSDM '08, 41(5), 207-218. doi:10.1145/1341531.1341559

AIMC. (2015). AIMC Marcas.

Akritidis, L., Katsaros, D., \& Bozanis, P. (2009). Identifying influential bloggers: Time does matter. Proceedings - 2009 IEEE/WIC/ACM International Conference on Web Intelligence, WI 2009, 1, 76-83. doi:10.1109/ WI-IAT.2009.18

Akritidis, L., Katsaros, D., \& Bozanis, P. (2011). Identifying the productive and influential bloggers in a community. Proceedings of the international conference on Web search and web data mining - WSDM '08, 41(5), 759-764. doi:10.1145/1341531.1341559

Armano, D. (2011). Pillars of the New Influence. Harvard Business Review. Retrieved from https://hbr.org/2011/01/the-six-pillars-ofthe-new-inf

Auty, S., \& Elliott, R. (1998). Fashion involvement, self-monitoring and the meaning of brands. Journal of Product \& Brand Management, 7(2), 109-123.

Berganza Conde, M. R., \& Ruiz San Román, J. A. (2005). Investigar en comunicación: Guía práctica de métodos y técnicas de investigación social en comunicación. MadridMcGraw Hill.

Brown, D., \& Fiorella, S. (2013). Influence marketing: How to create, manage, and measure brand influencers in social media marketing. Indianapolis, Indiana: Que Publishing.

Brown, D., \& Hayes, N. (2008). Influencer marketing: Who really influences your customers? Amsterdam: Elsevier/Butterworth-Heinemann.

Browne, B. A., \& Kaldenberg, D. O. (1997). Conceptualizing self-monitoring: Links to materialism and product involvement. Journal of Consumer Marketing, 14(1), 31-44. doi: 10.1108/07363769710155848

Burke, C. (2016). The state of influencer marketing. MAVRCK. Retrieved from https:// www.mavrck.co/mavrck-presents-thestate-of-influencer-marketing-ebook/

Burson-Marsteller. (2005). Burson-Marsteller identifies next generation of influencers. Retrieved from https://www.businesswire. com/news/home/20050329005104/en/ Burson-Marsteller-IdentifiesGeneration-Influencers-Tech-fluentialsNew-Chief

Cabosky, J. (2016). Social media opinion sharing: beyond volume. Journal of Consumer Marketing, 33(3), 172-181. doi:10.1108/ JCM-02-2015-1323

Cantoni, L., \& Tardini, S. (eds.) (2010). Generation $\mathrm{Y}$, digital learners, and other dangerous things QWERTY Interdisciplinary Journal of Technology, Culture, and Education, 5(2), 11-25.

Castells, M. (2001). La era de la información : economía, sociedad y cultura (Vol. 3). Madrid: Alianza, 1998 
Català, V. B. (2007). Las desigualdades en el consumo a través del género. Revista Española de Sociología, 8, 139-156.

Choi, T. M., Chiu, C. H., \& To, K. M. C. (2011). A fast fashion safety-first inventory model. Textile Research Journal, 81(8), 819-826. doi:10.1177/0040517510391697

Crane, D. (1999). Diffusion models and fashion: A reassessment. The Annals of the American Academy of Political and Social Science, 566(1), 13-24. doi:10.1177/000271629956600102

Crane, D. (2012). Fashion and its social agendas: Class, gender, and identity in clothing. Chicago: University of Chicago Press.

De Bruyn, A., \& Lilien, G. L. (2008). A multi-stage model of word-of-mouth influence through viral marketing. International Journal of Research in Marketing, 25(3), 151-163. doi:10.1016/j.ijresmar.2008.03.004

Estrada, R. E. L., \& Deslauriers, J.-P. (2011). La entrevista cualitativa como técnica para la investigación en Trabajo Social. Margen: revista de trabajo social y ciencias sociales, 61, 2-19.

Fromm, J., Butler, C., \& Dickey, C. (2015). How to engage Millennials: Re-imagining the consumer as a partner, not a target audience, to increase engagement. Journal of Brand Strategy, 4(1), 27-36.

Galeotti, A., \& Goyal, S. (2009). Influencing the influencers: a theory of strategic diffusion. The RAND Journal of Economics, 40(3), 509-532.

Gil Flores, J. (1993). La metodología de investigación mediante grupos de discusión. Enseñanza (No10-11, p. 199-214).

Gillin, P. (2007). The new influencers: A marketer's guide to the new social media. Sanger, CA : Quill Driver Books/Word Dancer Press, cop.

Gladwell, M. (2014). The tipping point: How little things can make a big difference. London: Abacus.

Guercini, S. (2014). New qualitative research methodologies in management. Management Decision, 52(4), 662-674. doi:10.1108/MD-11-2013-0592

Guercini, S., \& Runfola, A. (2015). Internationalization through e-commerce. the case of multibrand luxury retailers in the fash- ion industry. Advances in International Marketing, 26, 15-31. doi:10.1108/S1474797920150000026002

Guercini, S., Mir-Bernal, P., \& Prentice, C. (2018). New marketing in fashion e-commerce. Journal of Global Fashion Marketing, 9(1), 1-8. doi:10.1080/20932685.2018. 1407018

Harris, L., \& Rae, A. (2009). Social networks: The future of marketing for small business. Journal of Business Strategy, 30(5), 24-31. doi:10.1108/02756660910987581

Howe, N., \& Strauss, W. (2009). Millennials rising: The next great generation. New York: Vintage Books.

Johnson, B. W. C., \& Young, N. (2012). Power of Persuasion: Becoming the Influencer. Facilities Manager, 28(3), 30-34.

Jove, M. (2011). Influentials : Localizando líderes de opinión en el «El confidencial». Pamplona: Eunate, D. L.

Katz, E., \& Lazarsfeld, P. F. (1955). Personal influence. The part played by people in the flow of mass communications. New Brunswick and London: Transaction Publishers.

Keller, E., \& Berry, J. (2003). The influentials: One American in ten tells the other nine how to vote, where to eat, and what to buy. New York : Free Pr, 2003

Kiss, C., \& Bichler, M. (2008). Identification of influencers - Measuring influence in customer networks. Decision Support Systems, 46(1), 233-253. doi:10.1016/j. dss.2008.06.007

Klout (2013). The impact of identifying and measuring influencers in marketing. Retrieved from https://www.lithium. com/resources/white-papers/socialinfluencers-identifying-measuring-impact

Kruger, D., \& Byker, D. (2009). Evolved foraging psychology underlies sex differences in shoping experiences and behaviors. Journal of Social, Evolutionary, and Cultural Psychology, 3(4), 328-342. doi:10.1037/ h0099312

Martínez-Barreiro, A. (2006). La difusión de la moda en la era de la globalización. Papers. Facultad de Sociología, (2004), 187-204.

Mediakix. (2016). The CMO'S guide to influencer marketing. Retrieved from https://go.mediakix.com/influencermarketing-guide/ 
Mir-Bernal, P. (2014). Análisis de la reputación online aplicada al branding de empresa: Estudio comparativo sectorial en gran consumo. Universidad Abat Oliva CEU.

Mitchell, V., \& Walsh, G. (2004). Gender differences in German consumer decisionmaking styles. Journal of Consumer Behaviour, 3(4), 331-346.

Morgan, D. L. (1996). Focus groups as qualitative research (Vol. 16). Sage publications.

O'Cass, A. (2004). Fashion clothing consumption: antecedents and consequences of fashion clothing involvement. European Journal of Marketing, 38(7), 869-882. doi:10.1108/03090560410539294

Oblinger, D., Oblinger, J. L., \& Lippincott, J. K. (2005). Educating the net generation. Boulder, Colo.: EDUCAUSE, c2005. $1 \mathrm{v}$. (-various pagings): illustrations.

Olabuénaga, J. I. R., \& Ispizua, M. A. (1989). La descodificacion de la vida cotidiana: metodos de investigacion cualitativa. Universidad de deusto.

Onwuegbuzie, A. J., Johnson, R. B., \& Collins, K. M. T. (2011). Assessing legitimation in mixed research: a new Framework. Quality \& Quantity, 45(6), 1253-1271.

Pophal, L. (2016). Influencer marketing: turning taste makers into your best salespeople. EContent $V O-39$, (7), 18.

Portolese Dias, L. (2003). Generational buying motivations for fashion. Journal of Fashion Marketing and Management: An International Journal, 7(1), 78-86. doi:10.1108/13612020310464386

Raines, C. (2002). Managing millennials. Connecting Generations: The Sourcebook, 16.

Ranga, M., \& Sharma, D. (2014). Influencer Marketing - A marketing tool in the age of social media. Journal of Research in Managment and Technology, 3(8), 16-21. doi:10.1016/j.infsof.2008.09.005

Rapetti, E., \& Cantoni, L. (2013). Reconsidering "Gen Y" \& Co: From minding the gap to overcoming it. European Journal of Open, Distance and E-learning, 16(2).

Reeves, T. C., \& Oh, E. (2008). Generational differences. In J. M. Spector, M. D. Merrill, J.Elen, \& M. J. Bishop, M. J (eds.). Handbook of research on educational communications and technology (pp. 295-303). New York: Springer.
Rocha, M. A. V, Hammond, L., \& Hawkins, D. (2005). Age, gender and national factors in fashion consumption. Journal of Fashion Marketing and Management: An International Journal, 9(4), 380-390. doi:10.1108/13612020510620768

Rogers, E. M. (2010). Diffusion of innovations. New York: Simon and Schuster.

Sádaba, T. (2015). Moda en el entorno digital. Pamplona: EUNSA.

Sádaba, T., \& San Miguel, P. (2014). Revisión de los Influentials en moda con la aparición de Internet: estudio del caso español a través de Stylelovely.com. Revista de comunicación, (13), 60-83.

Sammis, K., Ng, J., Pomponi, S., \& Lincoln, C. (2015). Influencer Marketing For Dummies. Hoboken, NJ: For Dummies.

SanMiguel, P., \& Sádaba, T. (2018). Nice to be a fashion blogger, hard to be influential: An analysis based on personal characteristics, knowledge criteria, and social factors. Journal of Global Fashion Marketing, 9(1), 40-5.

Schaefer, M. W. (2012). Return on influence: the revolutionary power of Klout, social scoring, and influence marketing. New York : McGraw-Hill, cop..

Smith, K. T. (2011). Digital marketing strategies that Millennials find appealing, motivating, or just annoying. Journal of Strategic Marketing, 19(6), 489-499.

Smith, K. T. (2012). Longitudinal study of digital marketing strategies targeting Millennials. Journal of Consumer Marketing, 29(2), 86-92.

Smith, T., Coyle, J. R., Lightfoot, E., \& Scott, A. (2007). Reconsidering models of influence: the relationship between consumer social networks and word-of-mouth effectiveness. Journal of advertising research, 47(4), 387-397.

Solis, B. (2016). The Influencer Marketing Manifesto: Why The Future of Influencer Marketing Starts With People And Relationships Not Popularity. Altimeter Tapinfluence. Retrieved from https:// www.tapinfluence.com/tp_resource/ future-influencer-marketing/

Solis, B. (2017). Influence 2.0: The Future of Influencer Marketing. Retrieved from http://www2.traackr.com/influence2.0 
Solis, B., \& Webber, A. (2012). The Rise of Digital Influence. Altimeter Group. Retrieved from http://www.altimetergroup.com

Song, X., Chi, Y., Hino, K., \& Tseng, B. (2007). Identifying opinion leaders in the blogosphere. Proceedings of the sixteenth ACM conference on Conference on information and knowledge management CIKM 07, 07, 971-974. doi:10.1145/1321440.1321588

Tapinfluence. (2016). The future of influencer marketing.

Uzunoğlu, E., \& Misci Kip, S. (2014). Brand communication through digital influencers: Leveraging blogger engagement. International Journal of Information Management, 34(5), 592-602. doi: 10.1016/ j.ijinfomgt.2014.04.007

Watts, D. J., \& Dodds, P. S. (2007). Influentials, networks, and public opinion formation. Journal of consumer research, 34(4), 441-458.

Weimann, G. (1994). The influentials: People who influence people. SUNY Press.

Wiswede, G. (1971). Theorien der Mode aus soziologischer Sicht. Jahrbuch der Absatz-und Verbrauchsforschung, 17(1), 79-93.

WOMMA. (2017). The WOMMA Guide to Influencer Marketing.

Yoon, S.-J., \& Han, H.-E. (2012). Experiential approach to the determinants of online word-of-mouth behavior. Journal of Global Scholars of Marketing Science, 22(3), 218-234. doi:10.1080/21639159. 2012.699219

Zhang, L., Zhao, J., \& Xu, K. (2016). Who creates trends in online social media: The crowd or opinion leaders? Journal of Computer Mediated Communication, 21(1), 1-16. doi:10.1111/jcc4.12145 


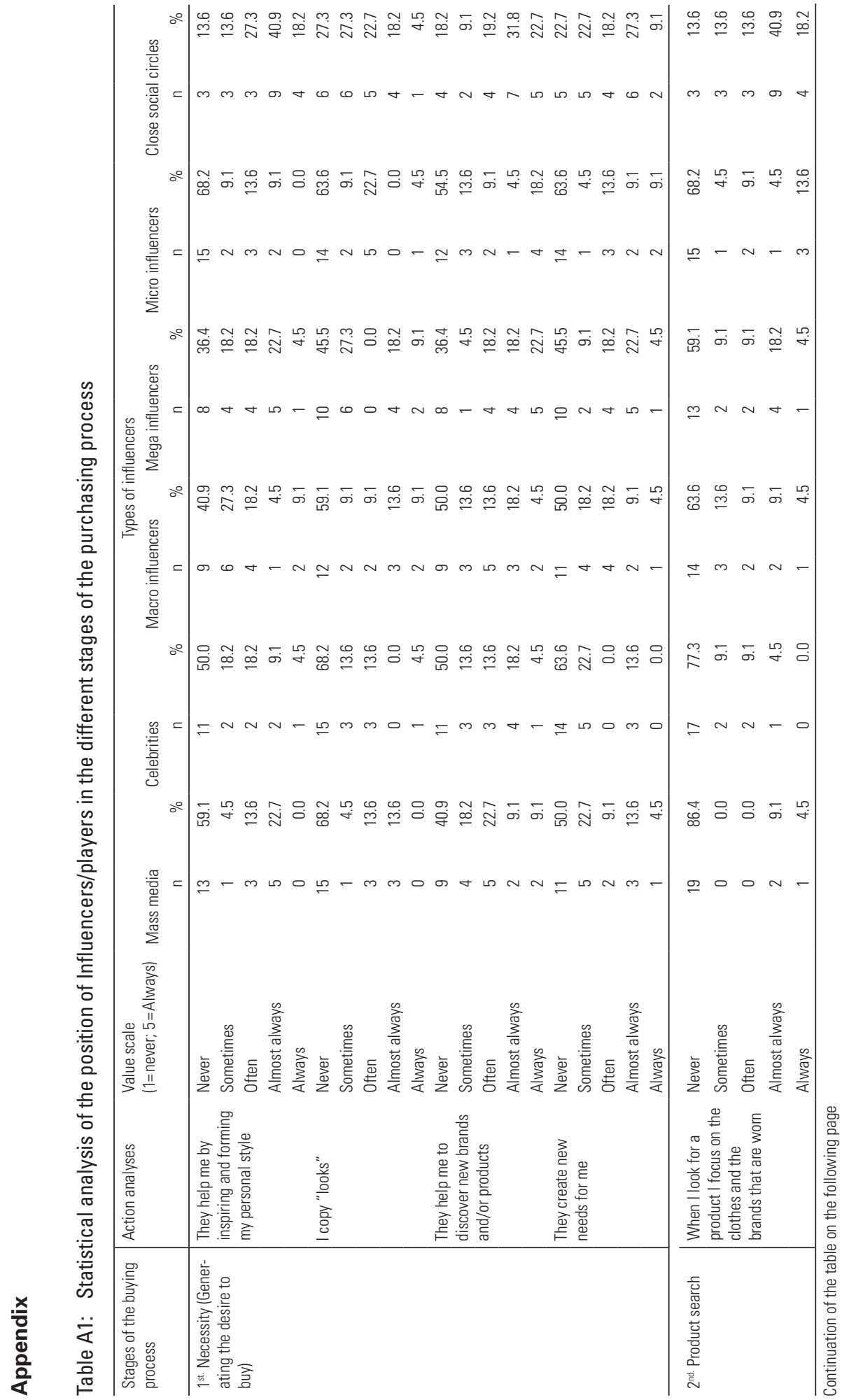




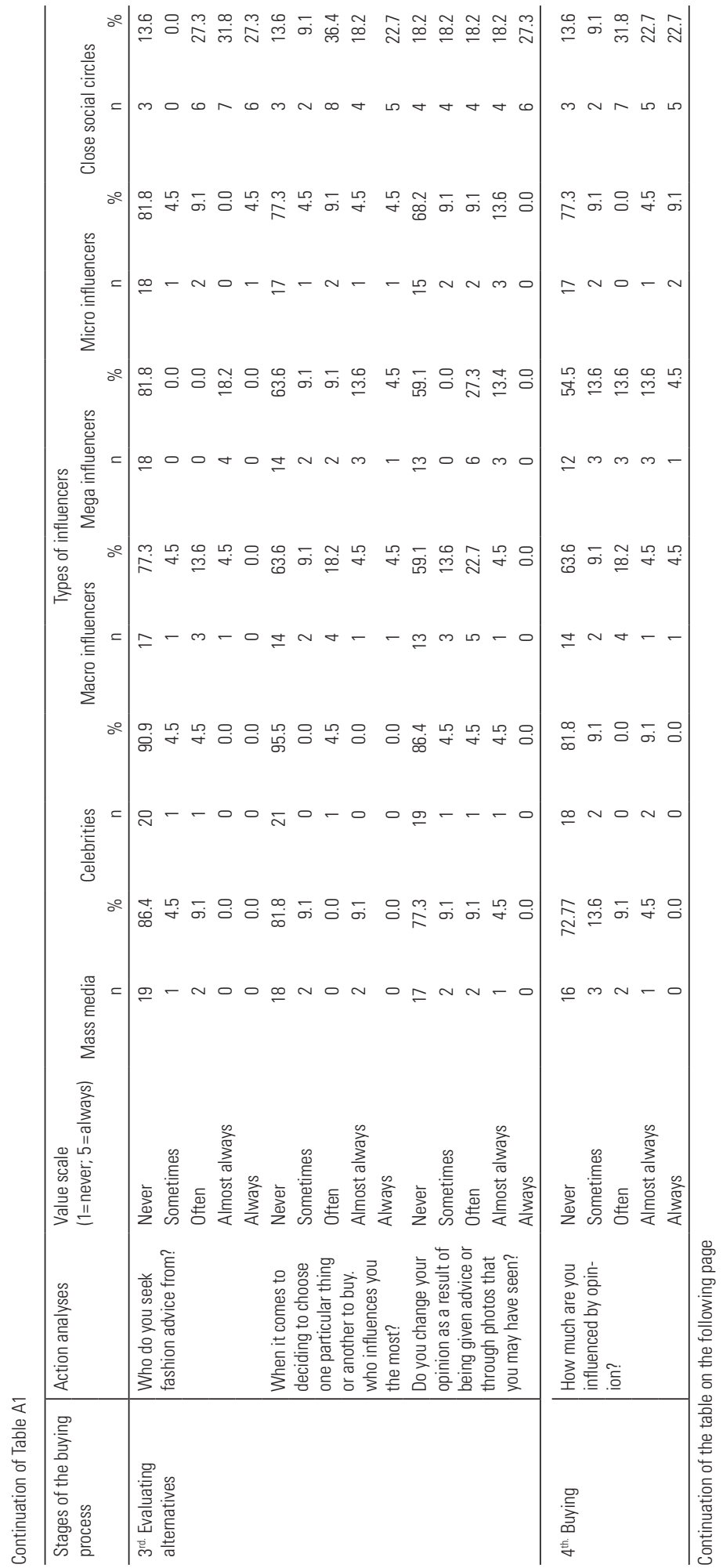




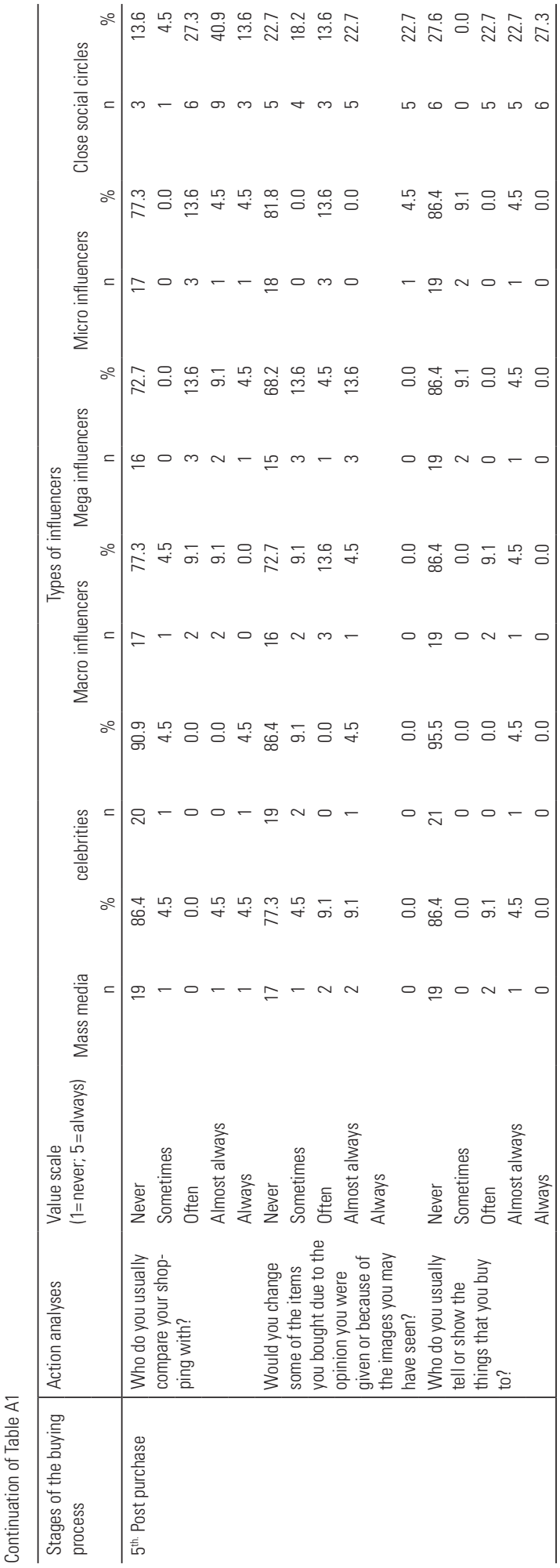

